\title{
Ubiquity of cyberchondria among Teachers: the case of basic and higher education institution (HEI) Teachers in Southern Philippines
}

\section{Ubiquidade de cibercôndria entre professores: o caso de professores de instituições de ensino superior (IES) no sul das Filipinas}

\section{Ubiquidad de la cibercondria entre los profesores: el caso de los profesores de las instituciones de educación básica y superior (HEI) del sur de Filipinas}

\begin{abstract}
Dennis Balanay Roble ${ }^{\text {(iD), Laila Salvaña Lomibao }}{ }^{1}$ iD), Maria Virginia Jones Valdez Maglipong1 (iD)
${ }^{1}$ Department of Mathematics Education, College of Science and Technology Education, University of Science and Technology of Southern Philippines, Cagayan de Oro City, Misamis Oriental, Philippines.
\end{abstract}

Corresponding author:

Dennis Balanay Roble

Email: dennis_roble@ustp.edu.ph

How to cite: Roble, D. B., Lomibao, L. S., \& Maglipong, M. V. J. V. (2021). Ubiquity of cyberchondria among Teachers: the case of basic and higher education institution (HEI) Teachers in Southern Philippines. Revista Tempos e Espaços em Educação, 14(33), e16066. http://dx.doi.org/10.20952/revtee.v14i33.16066

\begin{abstract}
The internet is a potential source of medical information. However, it can also be a source of increased anxiety and distress among people. This anxiety due to excess searching for medical information online is known as cyberchondria. Even before the COVID-19 global pandemic, research suggest that teachers' performance and productivity can also be negatively influenced by stress and anxiety. This study aimed to evaluate the cyberchondria constructs among teachers in the basic and higher education institutions in Cagayan de Oro City using the Cyberchondria Severity Scale (CSS15). Data are collected among the 143 basic and higher education teacher-respondents and results revealed that majority of them are affected with the compulsion (81.81\%), distress (93.71\%), excessiveness (98.6\%) and reassurance (90.91\%) constructs of cyberchondria with excessiveness construct being severely affected. There are only $28.67 \%$ of the teacher-respondents who are affected by mistrust of a medical professional. Further analysis showed that the cyberchondria constructs are independent and teachers from the basic and higher education institutions shared the same level of cyberchondriasis. Hence, it can be concluded that there is a high prevalence of cyberchondria among teachers and it is recommended that strategic interventions and measures need to be designed and implemented by school administrators to preserve teachers' wellbeing and foster positive teaching performance and students' learning outcomes.
\end{abstract}


Keywords: Cyberchondria severity scale (CSS-15). Cyberchondria. Distress. Health anxiety. Internet. Teachers' performance.

\section{RESUMO}

A internet é uma fonte potencial de informação médica. No entanto, também pode ser uma fonte de aumento da ansiedade e angústia entre as pessoas. Essa ansiedade devido ao excesso de busca de informações médicas online é conhecida como cybercondria. Mesmo antes da pandemia global COVID-19, pesquisas sugerem que o desempenho e a produtividade dos professores também podem ser influenciados negativamente pelo estresse e ansiedade. Este estudo teve como objetivo avaliar as construções cibernéticas entre professores das instituições de ensino fundamental e superior da cidade de Cagayan de Oro utilizando a Escala de Gravidade de Cybercondria (CSS-15). Os dados são coletados entre os 143 professores-entrevistados de ensino fundamental e superior e os resultados revelaram que a maioria deles é afetada com a compulsão $(81,81 \%)$, angústia $(93,71 \%)$, excesso $(98,6 \%)$ e tranquilidade $(90,91 \%)$ construções de cybercondria com construção de excesso sendo severamente afetada. Há apenas $28,67 \%$ dos professores-entrevistados que são afetados pela desconfiança de um profissional médico. Uma análise posterior mostrou que os construtos da cybercondria são independentes e os professores das instituições de ensino básico e superior compartilhavam o mesmo nível de cybercondria. Assim, pode-se concluir que há uma alta prevalência de cybercondria entre os professores e recomenda-se que intervenções estratégicas e medidas precisam ser projetadas e implementadas pelos gestores escolares para preservar o bemestar dos professores e promover o desempenho positivo do ensino e os resultados de aprendizagem dos alunos.

Palavras-chave: Angústia. Ansiedade. Cyberchondria. Desempenho dos professores. Escala de gravidade da cybercondria (CSS-15). Internet.

\section{RESUMEN}

Internet es una fuente potencial de información médica. Sin embargo, también puede ser una fuente de mayor ansiedad y angustia entre las personas. Esta ansiedad debida a la búsqueda excesiva de información médica en línea se conoce como cibercondrias. Incluso antes de la pandemia global de COVID-19, las investigaciones sugieren que el rendimiento y la productividad de los maestros también pueden verse influenciados negativamente por el estrés y la ansiedad. Este estudio tuvo como objetivo evaluar los constructos de cibercondrias entre docentes de las instituciones de educación básica y superior de la ciudad de Cagayán de Oro utilizando la Escala de Severidad de Cibercondrias (CSS-15). Los datos se recopilan entre los 143 docentes de educación básica y superior que respondieron y los resultados revelaron que la mayoría de ellos se ven afectados por los conceptos de compulsión $(81,81 \%)$, angustia $(93,71 \%)$, excesividad $(98,6 \%)$ y tranquilidad $(90,91 \%)$ de la cibercondría. con el constructo de excesos siendo severamente afectado. Solo el $\mathbf{2 8 , 6 7 \%}$ de los profesores-encuestados se ven afectados por la desconfianza hacia un profesional médico. Un análisis más detallado mostró que los constructos de cibercondrias son independientes y los profesores de las instituciones de educación básica y superior comparten el mismo nivel de cibercondriasis. Por lo tanto, se puede concluir que existe una alta prevalencia de cibercondrias entre los maestros y se recomienda que los administradores escolares diseñen e implementen intervenciones y medidas estratégicas para preservar el bienestar de los maestros y fomentar un desempeño docente positivo y los resultados del aprendizaje de los estudiantes.

Palabras clave: Angustia. Cybercondria severity scale (CSS-15). Cybercondria. Internet. Rendimiento de los profesores. Salud ansiedad. 


\section{INTRODUCTION}

Over the past decades, the use of the internet has become a vital tool for humans in their day to day life. In fact, it's the way people live and work in the current global workplace. The internet was widely utilized by the general public around the globe on their search for basic and advanced knowledge on the variety of fields as well as communicates and socially interacts with other people across the globe in just a second.

In the context of Filipino internet users, consistent with Sanchez (2020), the internet became widely available within the Philippines way back in 1994, which led to slowly developing internet savvy consumers within the country. As of January 2020, the number of internet users in the Philippines grew to 73 million people, accounting for quite half of the entire population. The digital population mostly belongs to the age group of 16 years old and above including teachers.

In particular, the internet could be a potential source of medical information among people because there are a variety of health websites which are readily accessible. However, this practice also can be a source of increased anxiety and distress. This anxiety due to excess searching for medical information online is referred as cyberchondria (Kanganolli \& Kumar, 2020) and this has become a very serious problem as a large number of people including teachers hunt for health information online. As argued by Himaad, Raveena, Vincy \& Oshin B (2020), cyberchondria, an adverse effect of the digital revolution, has affected the medical system by interrupting the line of treatment, elevating anxiety levels of participants, undermining the necessity for emergency care when necessary and most significantly, taking assistance of symptom checker sites in lieu of a physician's advice.

The COVID-19 communicable and infectious disease has remarkably disrupted all systems around the world. The exponential spread of this virus in many countries around the globe paved the way for unnecessary paranoia because the virus led to a dramatic loss of thousands of people's lives worldwide. In the educational system, most countries badly hit by the virus temporarily closed schools and shifted to online learning and other alternative delivery modes. In the Philippines, the Commission on Higher Education (CHED) for higher education institutions and the Department of Education (DEPED) for basic education enacted policies meant to secure the continuity of adherence of the stakeholders, particularly directed to the teachers and the students to the educational and preventive policies like the availability of different delivery modes of education and quarantine requirements (CHED, 2020; DEPED, 2020).

The global pandemic has impacted many teachers and students, most especially those in more vulnerable and disadvantaged communities, where remote learning is incredibly challenging. Many issues surfaced in adopting the "new normal" learning system and for many, psychological problems and important consequences in terms of mental health including stress, anxiety, depression, frustration, uncertainty during COVID-19 outbreak emerged progressively (Serafini, Parmigiani, Amerio, Aguglia, Sher \& Amore, 2020).

Even before the COVID-19 global pandemic, research suggest that teachers' performance and productivity are negatively influenced by stress and anxiety (Baghani \& Dehghan Neyshaboori, 2012; Schonfeld, Bianchi \& Luehring-Jones, 2017; Ferguson, Mang \& Frost, 2017) brought about by their job, working environment, family problems and unfortunate events just like the COVID-19 global pandemic. In line with Starcevic, Berle \& Arnáez (2020) the pandemic has been a fertile soil for cyberchondria because of the fear induced by COVID-19 ("coronaphobia", "COVID-19 anxiety"); the uncertainty associated with the fact that COVID-19 is a novel disease for which the world was poorly prepared; the abundance of online, unverified and constantly updated information on this disease; questionable trustworthiness of much information found online; and the decreased ability to filter out unnecessary information and the consequent information overload. During the pandemic, cyberchondria was more prominent among people who used social media as the main source of information about COVID-19 (Farooq, Laato \& Islam, 2020) possibly because much 
information about the pandemic obtained via social media was distorted and untrustworthy (Kouzy, Abi Jaoude, Kraitem, El Alam, Karam, Adib \& Baddour, 2020).

Although governments are all stepping up efforts to produce training and resources to support teachers in adapting to the present new learning modality, teachers are still pressured to adapt to this "new normal" learning delivery mode and at the same time keeping their life priorities such as their health and wellbeing. Hence, it is, therefore, a possibility that many teachers in the basic and higher education institutions had this excessive online look for medical information which may even be an engine for his or her chronic anxiety and distress. So as to stop the existence of cyberchondria among teachers, it's important to examine the prevalence of this emerging public psychological state problem among teachers as baseline information and suggest DEPED and CHED to design strategic measures to combat cyberchondria and foster teacher performance and productivity and hence, this study was conducted.

\section{LITERATURE REVIEW}

Aside from social interaction, teachers in various disciplines use the web for his or her online resources to be employed in their respective classes and at the same time they research on topics that are relevant to his or her personal and work life. In the current shift to the "new normal" learning modality because of the COVID-19 global pandemic, teachers are far more challenged to design their activities fitted to the kind of learning modality they are using in their respective schools and the internet assists teachers to effectively deliver their lessons in the different learning modalities. In fact, teachers also had to adapt to new pedagogical concepts and modes of delivery of teaching, for which they may not have been trained (OECD, 2020). Furthermore, as a protection against the spread of COVID-19 virus, per UNESCO (2020), quite 1 billion and 575 million students in approximately 188 countries around the world, including the Philippines, are reported to have been affected by the closure of basic education schools, colleges and universities. Together with these challenges, teachers may also experience stress and anxiety because of this health situation due to COVID-19 most importantly those teachers with comorbidities and serious health problems who are fearful of visiting hospitals and infected with the virus. Hence, in most cases, teachers might have also the tendency to look for informations over the internet about health problems, and cyberchondria can be prevalent among teachers in basic and higher education institutions.

Various research studies had already been conducted regarding cyberchondria. In terms of the inception of the word cyberchondria, according to Malik, Mustafa, Yaseen, Ghauri \& Javaeed (2019), the term cyberchondria stems from the words cyber and hypochondria. A cyber refer to a computer network, electronic medium, or computer within which online communication occurs while hypochondria refers to the condition in which an individual is unduly or excessively worried about having a selected disease. Consequentially, cyberchondria suggests a hypochondria associated with computer and internet use, probably caused by it. The source of the term isn't clear, but it's often traced back to a Wall Street Journal article in 1999 called as "On the net, diseases are rampant, playing to worries of hypochondriacs" by journalist Ann Carrns. The media has capitalized on the term and made it popular. As a result, most scientific and professional literature often cites online articles as their primary sources.

In Democratic Socialist Republic of Sri Lanka, a study conducted by Wijesinghe, Liyanage, Kapugama, Warsapperuma, Williams, Kuruppuarachchi \& Rodrigo (2019) on the prevalence, nature and effects of cyberchondria among outpatients, they discovered that among their 300 participants, majority of patients who made a self-diagnosis using online information had made an incorrect diagnosis. Further, one-third of internet users felt anxious after searching about their symptoms and $34 \%$ sought further medical advice following internet use. Hence, they suggest having public education regarding this matter and aware the people of Sri Lanka about the negative effects of online health information. 
In India, Dagar, Kakodkar \& Shetiya (2019) made an evaluation of the cyberchondria construct among 180 computer engineering students in Pune (India) using Cyberchondria Severity Scale (CSS-15) and they revealed that every one of the respondents were plagued by some or the other constructs of cyberchondria. This means that the web can affect an individual's mental, physical, and social activity by giving an unlimited amount of data and information and cause anxiety or distress associated with their search. Also, in another study conducted by Makarla, Gopichandran \& Tondare (2019) where they assess the prevalence and factors influencing cyberchondria among employees working within the information technology sector in India, they found out that the prevalence of cyberchondria was $55.6 \%$. The dominant pattern was excessiveness of online searching, requirement of reassurance followed by distress due to health anxiety and compulsivity. Cyberchondria was negatively related to general mental health after adjusting for age, sex, education, and years of service. They concluded that cyberchondria was an emerging public mental state problem in India. Since it's related to poor psychological state, measures have to be adopted to judge, prevent, and treat it at the population level.

In China, a scientific systematic review and meta-analysis conducted by Meng, Gao, Tang, Wang \& Tao (2019) on the prevalence of hypochondriac symptoms among 6,217 Chinese health science students revealed that there was a high prevalence of hypochondriac symptoms among health science students, indicating that it's a remarkable phenomenon. They suggest that counselling and other support services are necessary for health science students.

In the U.S. of America (USA), Fergus \& Dolan (2014) examined associations among Internet searches for medical information, health anxiety, and problematic Internet use (PIU) among 430 medically healthy community adults. As predicted, respondents who experienced increased health anxiety following Internet searches for medical information reported significantly greater PIU than respondents for whom such searches either had no impact on or decreased their health anxiety. This effect wasn't attributable to the frequency of health-related online searching behaviour or negative affect. Moreover, another study was conducted again by Fergus (2015) where he examined associations among anxiety sensitivity (AS), intolerance of uncertainty (IU), and cyberchondria dimensions among 578 community adults and this study provides evidence that specific AS and IU dimensions may confer vulnerability to certain cyberchondria dimensions. They also exclaimed that further clarifying associations among AS, IU, and cyberchondria may cause improvements in conceptualization and, ultimately, treatment of cyberchondria.

In the Netherlands, Baumgartner \& Hartmann (2011), through empirical investigation explored the link between health anxiety and online health information search using exploratory and experimental study. They investigated how can health anxiety influences the use of the Internet for health information and how health anxious individuals respond to online health information. An exploratory survey study with 104 Dutch participants indicates that health anxiety is related to an increase in online health information search. Moreover, results suggest that health anxious individuals experience more negative consequences from online health information search. Findings from an experimental study $(n=120)$ indicate that online health information results to bigger worries among health anxious people compared to non-health anxious individuals only if the information stems from a trustworthy governmental Web site. Information from a less trustworthy online forum does not result to bigger worries among health anxious people. In sum, the web seems to play a polar role within the lives of health anxious people.

In the United Kingdom (UK), Singh, Fox \& Brown (2016) obtained health anxious students' views on their reasons for using the Internet to get health information, and the nature and effects of such usage. Data were gathered using semi-structured interviews with twenty (20) postgraduate and undergraduate students known as extremely health anxious, and were examined using thematic analysis. Results steered that themes were organized by totally different stages of the search method. Reasons for searching enclosed curiosity, anxiety/worry concerning 
undiagnosed and unknown symptoms, and remedy-seeking. Both positive (e.g. reassurance) and negative (e.g. uncertainty) outcomes were reported. They noted that the Internet constitutes a crucial resource for getting health information by health anxious people, with the potential to each scale back and exacerbate health anxiety.

In Pakistan, Akhtar \& Fatima (2020) studied the development of cyberchondria and connected worries concerning health among people with none diagnosed medical condition. The survey-based, cross-sectional study was conducted from January to July 2018 in the twin cities of Rawalpindi and Islamabad, Pakistan, and comprised graduates of either gender aged a minimum of 35 years with access to the web and means of use, and with no current diagnosed medical condition. The self-reporting Cyberchondria Severity Scale was used data-collection in conjunction with a demographic sheet. Findings showed that a complete of $40(26.6 \%)$ subjects had low level of cyberchondria, whereas 35(23.3\%) experienced a higher level of it. Mean scores of men on total CSS were slightly higher than those of women $(p>0.05)$. Men also scored higher on compulsion, distress, excessiveness and reassurance subscales ( $p>0.05$ each), whereas girls scored slightly on top of men on 'mistrust of medical profession' subscale $(p>0.05)$. No significant gender variations were found on cyberchondria and its subscales ( $p>0.05$ each).

In Italy, Gioia \& Boursier (2020) tested the unexplored predictive role of perceived feelings of loneliness, general anxiety, depression, and stress on cyberchondria among women. A complete of 247 women with a mean age of 36.15 year old participated in the study. Results solely partly confirmed the direct impact of loneliness, depression, and stress. On the contrary, anxiety powerfully expected cyberchondriac symptoms, confirming the potential roundness of anxietycyberchondria relationship. The study incontestable novel findings within the field of health-related Internet use research and contributes toward the ongoing debate on potential predictors of cyberchondria.

In People's Republic of Bangladesh, another very interesting and recent study of cyberchondria during COVID-19 global pandemic conducted by Laato, Islam, Islam \& Whelan (2020)) reported that trust in online information and perceived information overload both intensified manifestations of COVID-19-related cyberchondria and steered "healthy scepticism" concerning health information and avoidance of information overload as ways of preventing or addressing cyberchondria. This study additionally found cyberchondria to be a "side effect" of the COVID-19 pandemic.

In the Philippines, one specific study was conducted by De la Cuesta, Catedrilla, Ebardo, Limpin, Leaño \& Trapero (2019) where they used a cross-sectional technique to analyse the link between individual temperament traits and cyberchondria using an online survey among students officially enrolled within the Bachelor of Science in Nursing program from two Philippine universities. The structural model they have developed indicated that a high level of conscientiousness and neuroticism had a positive relationship to cyberchondria at a significant level. This means that individuals with a higher score for conscientiousness and neuroticism are likely to hunt information concerning the illness over the web. They suggested that future medical professionals, nursing students have the moral obligation to develop critical appraisal skills to spot on the data that is valid and reliable. Also, internet stakeholders have to be compelled to collaborate to make sure that medical information available are those that are scientifically verified to alleviate the negative effects of cyberchondria to its users (O'Mathúna, 2018).

Certainly, looking at the above intercontinental review on studies about cyberchondria, there was no study conducted in the Philippines, aside from De la Cuesta, Catedrilla, Ebardo, Limpin, Leaño \& Trapero (2019) research study, most especially during the COVID-19 global pandemic among teachers. The impact of the COVID-19 global pandemic on education is clearly manifested on teachers and students anxiety and distress brought about by their unpreparedness of embracing the "new normal" teaching and learning. Hence, there is a need to study on the existence of 
cyberchondria syndrome among teachers because it would have an effect on their teaching performance. How can teachers be more effective in teaching in the "new normal" where they themselves are having anxiety and distress over their health problems? Although not all teachers might have personal health problems but a family member experiencing it can also affect people around and teachers being a "researcher" can exercise this skill by searching health informations online.

\section{METHODOLOGY}

This study employed descriptive survey method to collect the data from the randomly selected 143 basic and higher education institution teachers in Cagayan de Oro City, Misamis Oriental in the Philippines using the Cyberchondria Severity Scale (CSS-15) to determine the prevalence of cyberchondria among teachers. This highly urbanized city and regional centre was located in the Northern Mindanao region. The location of this city was shown in the following figure:

Figure 1. Map of Cagayan de Oro City in Northern Mindanao Region, Philippines.

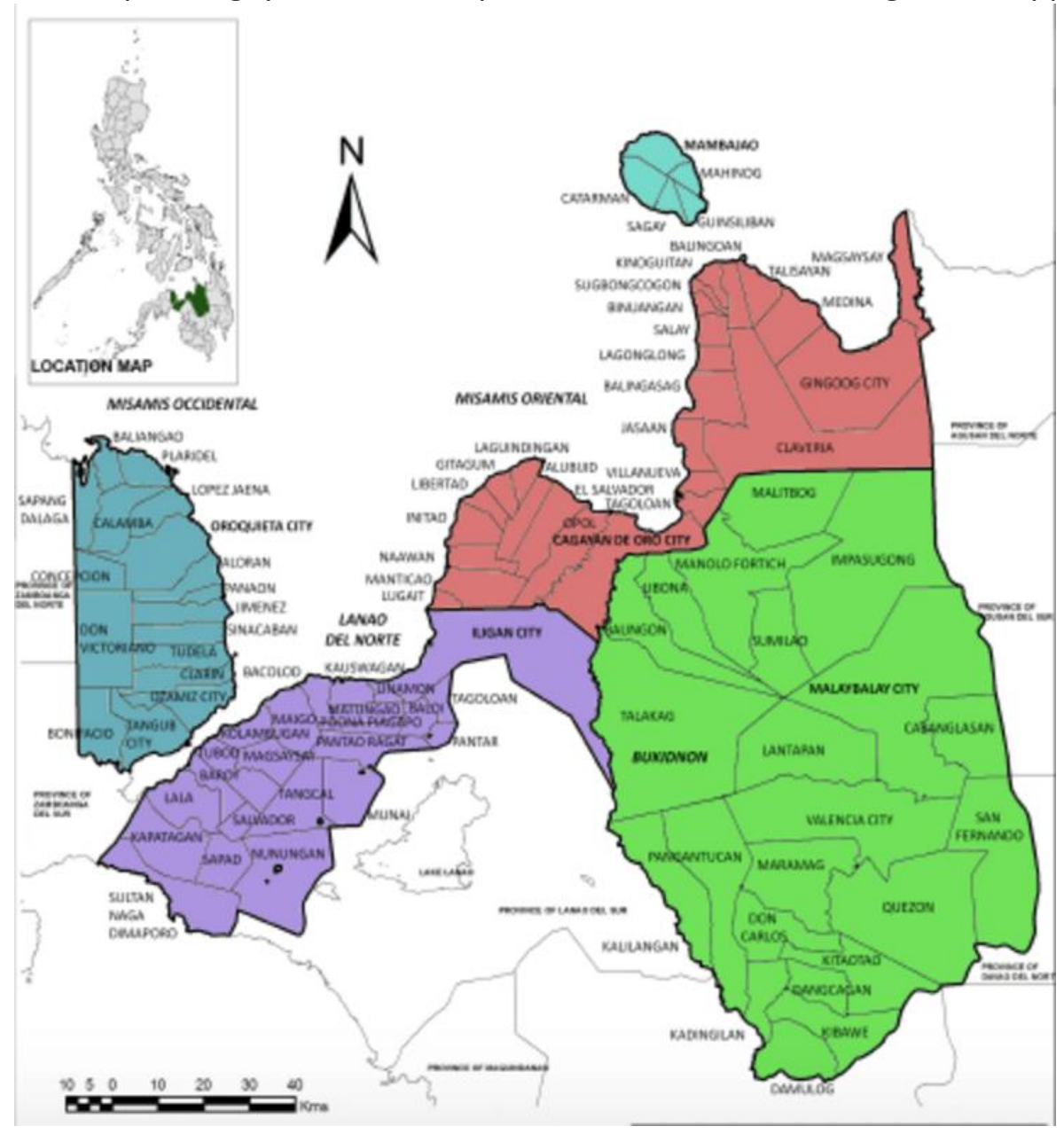

The CSS-15 (with 15 items) administered to the teacher-respondents was originally CSS-33 (with 33 items) constructed by McElroy \& Shevlin (2014) and it was based on a solid theoretical framework, with very good to excellent reliability and validity. This instrument has been translated into several languages over a period of time (e.g., Silva, Andrade, Silva \& Cardoso (2016)) made a translated version of CSS that has semantically adapted for the Brazilian population). The revisions of the original version of the CSS have been introduced to refine its conceptual foundation and improve its utility by making it shorter, hence this study utilized the shorter version CSS-15 but retained its good psychometric properties similar to CSS-33. The CSS-15 contains five (5) constructs, 
namely, compulsion, distress, excessiveness, reassurance and mistrust of a medical professional. Each of these constructs contains three (3) questions. The next table shows the attributes of the different constructs:

Table 1. Attributes of the Cyberchondria Constructs (Dagar, Kakodkar \& Shetiya, 2019).

\begin{tabular}{|c|c|}
\hline Cyberchondria Constructs & Attributes \\
\hline Compulsion & $\begin{array}{c}\text { Searching symptoms online and interrupting the time to be used } \\
\text { for work related and leisure activities. }\end{array}$ \\
\hline Distress & Panic, anxiety and disturbed sleep. \\
\hline Excessiveness & $\begin{array}{l}\text { Repetition and spending unnecessary time researching the same } \\
\text { symptom and health condition on the internet. }\end{array}$ \\
\hline Reassurance & $\begin{array}{l}\text { Anxiety, manifesting the need for reassurance from a more } \\
\text { qualified person, i.e. a medical professional. }\end{array}$ \\
\hline Mistrust of a Medical Professional & $\begin{array}{c}\text { Trusting the expert (medical professional) diagnosis than self- } \\
\text { diagnosis. }\end{array}$ \\
\hline
\end{tabular}

Because of the COVID-19 global pandemic, the CSS-15 survey questionnaire was carried out using Google forms. In order to ensure respect for anonymity and dignity of the participants and adequate level of confidentiality of the data collected from the participants, they are given informed consent and also in compliance with the Republic Act No. 10173, otherwise known as the Data Privacy Act of the Philippines. Informed consent provides the participants as well as the government repositories with sufficiently detailed information on the study so that they can make an informed, voluntary and rational decision to participate in the study. Data collected were analyzed descriptively using frequency count, percentage, mean and standard deviations.

\section{RESULTS AND DISCUSSION}

Out of 143 randomly selected teacher-respondents, 82 (57.34\%) are female while 61 $(42.66 \%)$ are male with a mean age of 34.10 years old. Majority of them are married teachers while $88(61.54 \%)$ are teaching in the basic education and $55(38.46 \%)$ from higher education institutions in Cagayan de Oro City. The results of the responses of the teacher-respondents on the CSS-15 survey questionnaire were shown in the following table and figures:

Table 2. Frequency and Percentage Distribution of Teachers Affected by Cyberchondria Constructs using CSS-15.

\begin{tabular}{cccc}
\hline CSS-15 Constructs & Not Affected & Moderately Affected & Severely Affected \\
\hline Compulsion & $26(18.18 \%)$ & $109(76.22 \%)$ & $8(5.59 \%)$ \\
Distress & $9(6.29 \%)$ & $117(81.82 \%)$ & $17(11.89 \%)$ \\
Excessiveness & $2(1.40 \%)$ & $85(59.44 \%)$ & $56(39.16 \%)$ \\
Reassurance & $13(9.09 \%)$ & $104(72.73 \%)$ & $26(18.18 \%)$ \\
Mistrust of a Medical Professional & $101(70.63 \%)$ & $41(28.67 \%)$ & $0(0 \%)$ \\
\hline
\end{tabular}

The overall survey results showed the majority of the teacher-respondents were getting affected by the different constructs of cyberchondria except for the mistrust of a medical professional. In particular, the excessiveness construct showed the highest percentage of teacherrespondents getting affected, i.e. $98.6 \%(59.44 \%=$ moderately affected \& $39.16 \%$ = severely affected) of the teacher-participants are repetitively searching the same symptoms and health conditions in the internet. Distress construct showed the second highest percentage of teacherrespondents getting affected, which comprises $93.71 \%(81.82 \%=$ moderately affected $\& 11.89 \%=$ severely affected) of all respondents. The reassurance construct came third with $90.91 \%$ of the teacher-respondents getting affected, where $72.73 \%$ are moderately affected and $18.18 \%$ are severely affected. In terms of compulsion construct $81.81 \%$ of the teacher-respondents are affected 
where $76.22 \%$ are moderately affected and $5.59 \%$ are severely affected. Overall, teachers in the basic education and higher education institutions are affected by cyberchondria constructs and this condition needs proper measures and strategic interventions most especially that many are severely affected by these constructs. This is consistent with the results of the study of Dagar, Kakodkar \& Shetiya (2019) and Makarla, Gopichandran \& Tondare (2019) where they found out that the prevalence of cyberchondria among majority of their participants. Further, the present study showed quite similar dominant pattern of the latter study of the different constructs from excessiveness of online searching, requirement of reassurance followed by distress due to health anxiety and compulsivity. Although majority of the teacher-respondents (70.63\%) are not affected by the mistrust of a medical professional construct which implies that they are confident with the information given by a medical professional, however, it is a sad reality that there are $28.67 \%$ affected. This indicates that some teachers are still paranoid and failed to take comfort from medical professionals regarding their health conditions, hence, they resort to the internet information, and however, the internet constitutes an important resource for obtaining health information by health anxious individuals, with the potential to both reduce and exacerbate health anxiety (Singh, Fox \& Brown, 2016).

Furthermore, the normality of the score distribution of the different constructs of cyberchondria was shown in the following figures:

Figure 2. Cyberchondria Constructs Normal Score Distribution.

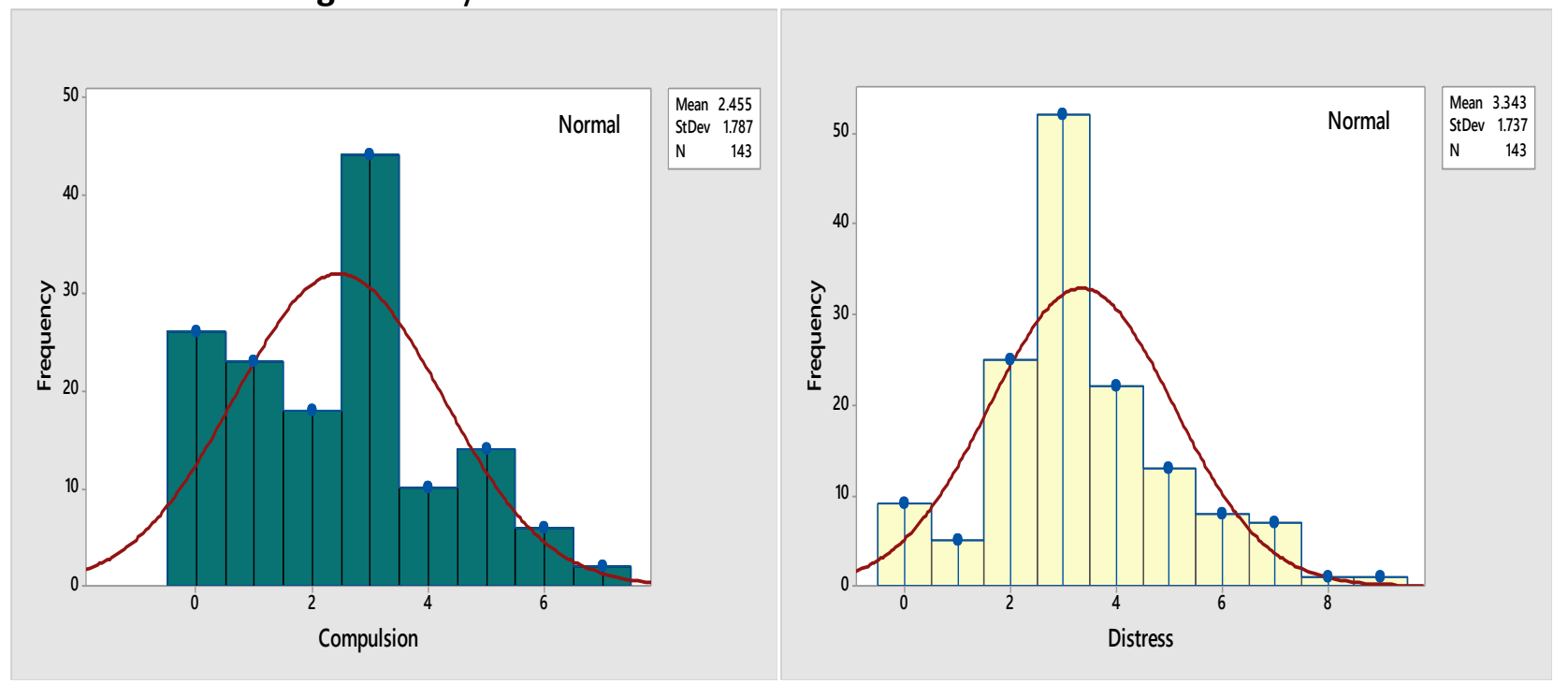

Figure 2.a

Figure 2.b 


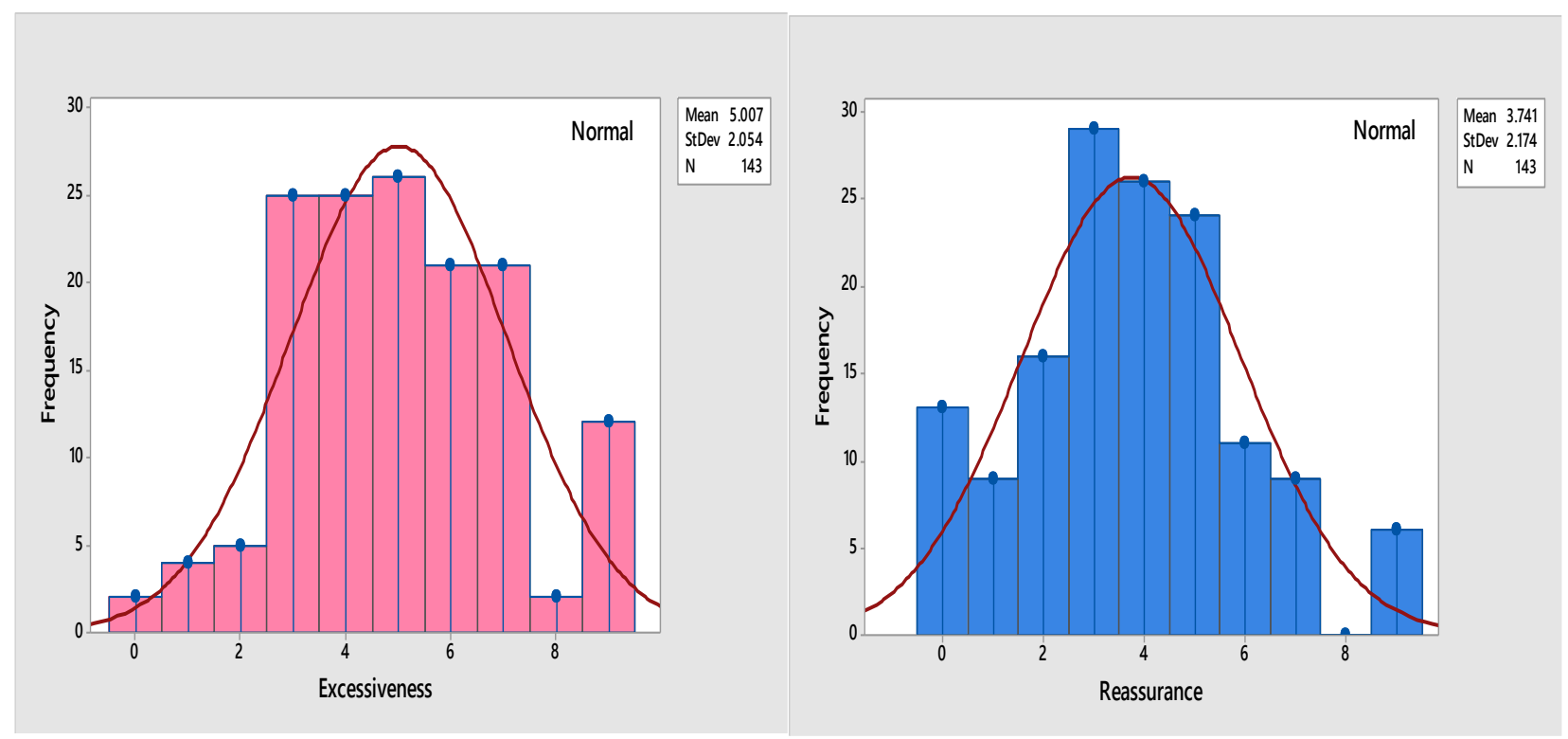

Figure 2.c

Figure 2.d

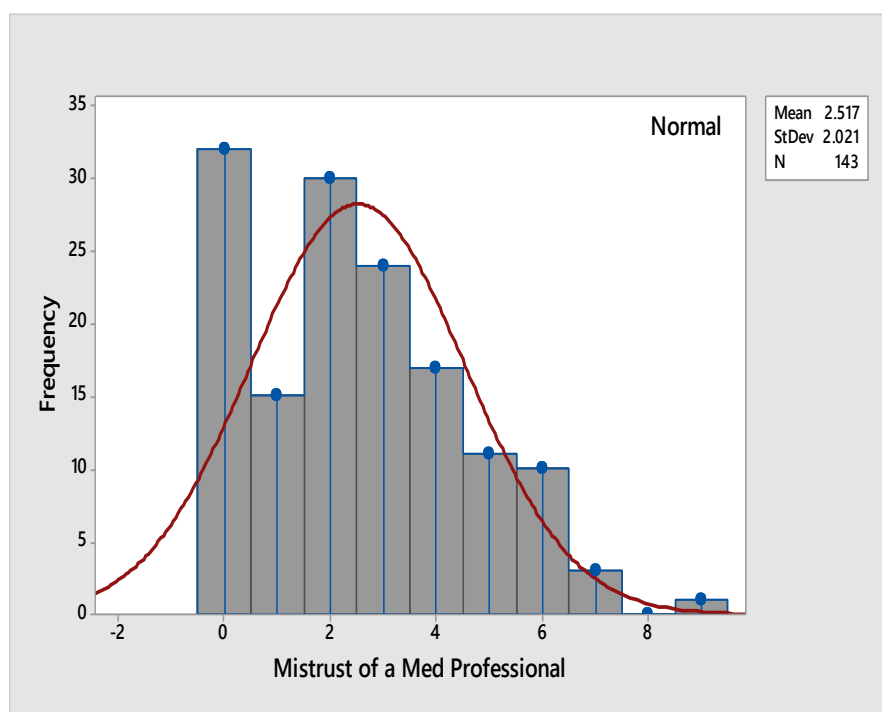

Figure 2.e

The score distribution of the 143 teacher-respondents on the five constructs of cyberchondria showed a normal distribution which indicates that the data gathered was statistically correct. The excessiveness (see Fig.2c) construct obtained the highest mean score of 5.01 with standard deviation of 2.054 while the compulsivity (see Fig.2a) construct got the lowest mean score of 2.45 with standard deviation of 1.787. This is consistent with the previous result indicating that the excessiveness construct had the greatest impact on the teacher-respondents, that is, they search for health-related symptoms over and over again in the internet. These results corroborate the findings of the study of Dagar, Kakodkar \& Shetiya, (2019) where in fact all of their computer engineering student-participants are affected by excessiveness construct of cyberchondria. 
Table 3. Correlation Matrix for the CSS-15 Constructs Test of Association.

\begin{tabular}{ccccc}
\hline CSS-15 Constructs & Compulsion & Distress & Excessiveness & Reassurance \\
\hline Distress & $0.490^{*}$ & & & \\
Excessiveness & $0.290^{*}$ & $0.299^{*}$ & & \\
Reassurance & 0.132 & $0.277^{*}$ & $0.294^{*}$ & \\
Mistrust of a Medical Professional & -0.073 & 0.091 & $0.191^{*}$ & $0.316^{*}$ \\
\hline
\end{tabular}

*Significant at $\mathrm{p}<0.05$ alpha level.

The information showed in table 3 shows the association of the CSS-15 constructs. The association between distress and compulsion showed the highest magnitude and significant correlation however their association is not strong which indicates that distress and compulsion indicators of cyberchondria are related but not very high. This is an important indication that these constructs are independent domains which particularly measures independent characteristics of cyberchondriasis. Other constructs showed weak positive correlations except for the no linear association between the mistrust of a medical professional and compulsion as well as distress which indicates that these variables are independent.

The following table shows the comparison of the basic and higher education institutions teachers prevalence of cyberchondria:

Table 4. Comparison of Basic and HEI Teachers Level of Cyberchondriasis.

\begin{tabular}{ccc}
\hline CSS-15 Constructs & F-value & p-value \\
\hline Compulsion & 0.51 & 0.678 \\
Distress & 0.18 & 0.913 \\
Excessiveness & 0.13 & 0.941 \\
Reassurance & 0.05 & 0.985 \\
Mistrust of a Medical Professional & 1.79 & 0.152 \\
\hline
\end{tabular}

*Significant at $\mathrm{p}<0.05$ alpha level.

The information in table 4 conveys that teachers in the basic and higher education institutions have the same level of cyberchondriasis in all of its constructs. This implies that the levels of cyberchondria among the respondents are not significantly different from each other. Regardless of their teaching assignment, they had the same level of cyberchondriasis.

\section{CONCLUSION}

The internet can indeed be both a resource of excellent and unhealthy information. Cyberchondria is becoming very prevalent in society across all countries over the world and teachers in the basic and higher education institutions were not an exemption to this health-related online search problem considering the above findings. In fact, cyberchondriasis was considered to be a mental health problem (Malik, Mustafa, Yaseen, Ghauri \& Javaeed, 2019) and if teachers experienced this personal health dilemma, it is important that DEPED and CHED authorities to consider designing programs and activities that promote health literacy among them. It should be remembered that mental health is linked to the balance between mind and body, as a requirement for happiness (Soares, Estanislau, Brietzke, Lefèvre \& Bressan (2014) and when teachers are happy then they will presumably perform well in their teaching, despite the worldwide pandemic. It should be noted that the COVID-19 global pandemic conjointly poses a more challenging demands for both basic and higher education institution teachers and as argued by Laato, Islam, Islam \& Whelan (2020), trust in online information and perceived information overload both intensified manifestations of COVID-19-related cyberchondria and in fact cyberchondria is a "side effect" of the COVID-19 pandemic. Moreover, international and national health organizations such as the World Health Organization (WHO) and the Department of Health (DOH) in the Philippines may additionally 
study on the way to regulate health information on the internet. One of the constraints of this study is the use of the CSS-15 which can have socio-cultural and contextual effect and therefore it is suggested to develop an identical instrument in the Philippines, just like what other countries have developed with consistent psychometric properties with the original CSS. Future analysis may be also conducted to deepened understanding of cyberchondria and efforts to forestall it.

Authors' Contributions: Roble, D. B.: conception and design, acquisition of data, analysis and interpretation of data, drafting the article, critical review of important intellectual content; Lomibao, L. S.: conception and design, acquisition of data, and analysis and interpretation of data; Maglipong, M. V. J. V.: conception and design, acquisition of data, and analysis and interpretation of data. All authors have read and approved the final version of the manuscript.

Ethics Approval: Not applicable.

Acknowledgments: Not applicable.

\section{REFERENCES}

Akhtar, M., \& Fatima, T. (2020). Exploring cyberchondria and worry about health among individuals with no diagnosed medical condition. J Pak Med Assoc, 70, 90-95.

Baghani, M., \& Dehghan Neyshaboori, M. (2012). Impact of teachers' anxiety on teaching quality. Iranian Quarterly of Education Strategies, 5(1), 9-13.

Baumgartner, S. E., \& Hartmann, T. (2011). The role of health anxiety in online health information search. Cyberpsychology, behavior, and social networking, 14(10), 613-618.

Commission on Higher Education (2020). COVID-19 Updates - Advisory 6. Quezon City, PH: CHED.

Dagar, D., Kakodkar, P., \& Shetiya, S. H. (2019). Evaluating the cyberchondria construct among computer engineering students in Pune (India) Using Cyberchondria Severity Scale (CSS-15). Indian Journal of Occupational and Environmental Medicine, 23(3), 117.

De La Cuesta, J., Catedrilla, J., Ebardo, R., Limpin, L., Leaño, C., \& Trapero, H. Personality traits of future nurses and cyberchondria: Findings from an Emerging Economy.

Department of Education (2020). Learning while staying at home: teachers, parents support deped distance learning platform. Pasig City, PH: DepEd.

Farooq, A., Laato, S., \& Islam, A. N. (2020). Impact of online information on self-isolation intention during the COVID19 pandemic: cross-sectional study. Journal of medical Internet research, 22(5), e19128.

Fergus, T. A. (2015). Anxiety sensitivity and intolerance of uncertainty as potential risk factors for cyberchondria: A replication and extension examining dimensions of each construct. Journal of affective disorders, 184, 305-309.

Fergus, T. A., \& Dolan, S. L. (2014). Problematic internet use and internet searches for medical information: the role of health anxiety. Cyberpsychology, Behavior, and Social Networking, 17(12), 761-765.

Ferguson, K., Mang, C., \& Frost, L. (2017). Teacher stress and social support usage. Brock Education: A Journal of Educational Research and Practice, 26(2), 62-86.

Gioia, F., \& Boursier, V. (2020). What does predict cyberchondria? Evidence from a sample of women. Journal of Psychology, 7, 69.

Himaad H., Raveena K., Vincy K., \& Oshin B., (2020). Cyberchondria: prevalence of internet based self-diagnosis among medical and non-medical Urban Indian population. International Journal of Contemporary Medical Research, 7(3), 2125.

Kanganolli SR, Kumar NP. (2020). A crosssectional study on prevalence of cyberchondria and factors influencing it among undergraduate students. Int J Med Sci Public Health, 9(4), 63-266.

Kouzy, R., Abi Jaoude, J., Kraitem, A., El Alam, M. B., Karam, B., \& Adib, E. \& Baddour, K.(2020). Coronavirus goes viral: quantifying the COVID-19 misinformation epidemic on Twitter.

Laato, S., Islam, A. N., Islam, M. N., \& Whelan, E. (2020). What drives unverified information sharing and cyberchondria during the COVID-19 pandemic?. European Journal of Information Systems, 29(3), 1-18. 
Makarla, S., Gopichandran, V., \& Tondare, D. (2019). Prevalence and correlates of cyberchondria among professionals working in the information technology sector in Chennai, India: A cross-sectional study. Journal of Postgraduate Medicine, 65(2), 87.

Malik, M. N., Mustafa, M. A. T., Yaseen, M., Ghauri, S. K., \& Javaeed, A. (2019). Assessment of cyberchondria among patients presenting to the emergency department of three hospitals in Islamabad, Pakistan. South Asian J Emerg Med (SAJEM), 2, 19-23.

McElroy, E., \& Shevlin, M. (2014). The development and initial validation of the cyberchondria severity scale (CSS). Journal of anxiety disorders, 28(2), 259-265.

Meng, J., Gao, C., Tang, C., Wang, H., \& Tao, Z. (2019). Prevalence of hypochondriac symptoms among health science students in China: A systematic review and meta-analysis. PloS one, 14(9), e0222663.

O’Mathúna, D. P. (2018). How Should Clinicians Engage With Online Health Information?. AMA journal of ethics, 20(11), 1059-1066.

OECD (2020), Education at a Glance 2020: OECD Indicators, OECD Publishing, Paris.

Schonfeld, I. S., Bianchi, R., \& Luehring-Jones, P. (2017). Consequences of job stress for the mental health of teachers. In Educator stress. Springer: Cham, pp. 55-75.

Serafini, G., Parmigiani, B., Amerio, A., Aguglia, A., Sher, L., \& Amore, M. (2020). The psychological impact of COVID-19 on the mental health in the general population. QJM: An International Journal of Medicine, 113(8), 531-537.

Singh, K., Fox, J. R., \& Brown, R. J. (2016). Health anxiety and Internet use: A thematic analysis. Cyberpsychology: Journal of Psychosocial Research on Cyberspace, 10(2), 2-4.

Soares, A. G. S., Estanislau, G., Brietzke, E., Lefèvre, F., \& Bressan, R. A. (2014). Public school teachers' perceptions about mental health. Revista de saude publica, 48, 940-948.

Starcevic, V., Berle, D., \& Arnáez, S. (2020). Recent insights into cyberchondria. Current Psychiatry Reports, 22(11), 1-8.

UNESCO (2020), COVID-19 educational disruption and response, UNESCO website, https://en.unesco.org/covid19/educationresponse (accessed on 25 June 2020).

Wijesinghe, C. A., Liyanage, U. L. N. S., Kapugama, K. G. C. L., Warsapperuma, W. A. N. P., Williams, S. S., Kuruppuarachchi, K. A. L. A., \& Rodrigo, A. (2019). "Muddling by googling"-Cyberchondria among outpatient attendees of two hospitals in Sri Lanka. Sri Lanka Journal of Psychiatry, 10(1), 11-15.

Received: 8 July 2021 | Accepted: 9 August 2021 | Published: 14 August 2021 